\title{
Marxism and Educational Theory
}

Mike Cole

\section{Summary}

While Marx and Engels wrote little on education, the educational implications of Marxism are clear. Education both reproduces capitalism and has the potential to undermine it. This entry, therefore, takes each of these propositions in turn. With respect to reproduction, it is informative to look at key texts by Althusser and Bowles and Gintis (and the latter's legacy). As far as challenging capitalism is concerned, considerations are given of both theoretical developments and practical attempts to confront neoliberalism and enact socialist principles, the combination of which Marxists refer to as praxis. There have been constant challenges to Marxism since its conception, and the entry concludes with a look at two contemporary theories - Critical Race Theory and its primacy of 'race' over class - and intersectionality which has a tendency to marginalize class.

Keywords: Marxism, Educational Theory, education and the reproduction of capitalism, Althusser, Bowles and Gintis, education and the undermining of capitalism, Rikowski, Neary and Saunders, contemporary theoretical challenges to Marxism.

\section{Marx and Engels on Education}

As Ronald F. Price (1977, p. 68) has argued, Marx's vision of communism as the transcendence of alienation, and of a period when people become increasingly self-conscious and selfdetermining has manifold implications for education. However, for Marx and Engels the transformation of society is to come about through class struggle, and class action, rather than as a result of the spread of enlightened opinion throughout society; thus education did not figure prominently in their work, at least in the sense of being educated formally in institutions.

While formal education did not occupy a major part of Marx and Engels' time, both believed the fostering of 'a full knowledge of the conditions and of the meaning' of the overthrow of capitalism was necessary to enact this basic structural change. Whether, as for Marx and Engels it is the working class who are 'called upon to accomplish' 'the momentous act' (Engels, 1892 [1977], p. 428), or agents of change are seen more broadly, as is the case with Open Marxism, the nurturing of such revolutionary knowledge is a central task for all Marxists.

Marx noted that the bourgeoisie fail to offer real education and, instead, education is used to spread bourgeois moral principles (Marx, 1847, cited in Taylor, 1995, p. 19). Marx and Engels also argued, however, that workers are educated very much by their experiences of labour under capitalism, and Marx, in fact, believed that, from the age of nine, education in schools should be combined with labour. Marx and Engels felt that combining education with labour would increase general awareness of the (exploitative) nature of capitalism. Engels (1845) [1975], p. 243) believed that 'an educated proletariat will not be disposed to remain in the oppressed condition in which our present proletariat finds itself', and thus believed that education could contribute to increased

awareness. For Marxist educationists, therefore, there are two interrelated issues which are of importance with respect to education under capitalism: first how and to what extent does education reproduce capitalism; second, in what ways might education in capitalist societies undermine capitalism? Here I address institutional education only. Elsewhere (Cole, 2018, chapter 6), I 
discuss the role of public pedagogy (that which takes place outside educational establishments) in challenging capitalism and promoting socialism. ${ }^{1}$

\section{Education and the reproduction of capitalism Louis Althusser on education}

It is first necessary to understand the role of education in capitalist society. Neo-Marxist Louis Althusser (1971) differentiates between what he calls the Repressive State Apparatuses (RSAs) (government, administration, army, police, courts, prisons) and the Ideological State Apparatuses (ISAs) (religion, education, family, law, politics, trade unions, communication, culture). The RSAs operate primarily by force and control. The $I S A s$, on the other hand, operate primarily through ideology. However, it needs to be pointed out that the two state apparatuses function both by violence and by ideology.

For Althusser, whereas the religious ISA (system of different churches) historically used to be the major ISA, 'the ISA which has been installed in the dominant position in mature capitalist social formations ... is the educational ideological apparatus . . . [it is] number one' (Althusser, 1971, p. 153). Althusser argued that schools are particularly important for inculcating the dominant ideology, since no other ISA requires compulsory attendance of all children eight hours a day for five days a week. Althusser suggested that what children learn at school is 'know-how' - wrapped in the ruling ideology of the ruling class. As fellow neo-Marxist Madan Sarup (1983, p. 13) put it: 'in this system each mass of children ejected en route is practically provided with the ideology which suits the role it has to fulfil in class society'. One of the advantages to the ruling class of the educational ISA is that, while given its high profile in party political rhetoric, education, in everyday usage, is no longer perceived as neutral in a party political sense, it is certainly not thought of as an agent of cultural and economic reproduction. ${ }^{2}$

\section{The Bowles and Gintis moment and its legacy}

For many, the publication of Schooling in Capitalist America (SCA) by Sam Bowles and Herb Gintis (1976) was a major breakthrough: an analysis, which made the capitalist economy central to an understanding of processes in schools. The key concept in SCA is 'the correspondence principle' - the reproduction of social relations of production is facilitated through a structural correspondence between the social relations of education and those of production. 'To reproduce the social relations of production', Bowles and Gintis (1976, p. 130) argue, 'the education system must try to teach people to be properly subordinate and render them sufficiently fragmented in consciousness to preclude their getting together to shape their material existence'. Specifically, according to The Correspondence Principle, 'the educational system helps integrate youth into the economic system ... through a structural correspondence between its social relations and those of production' (ibid., p. 131; my emphasis). It is worth quoting Bowles and Gintis (ibid.) at length:

The structure of social relations in education not only inures the student to the discipline of the work place, but develops the types of personal demeanor, modes of self-presentation, self-image, and social-class identifications which are the crucial ingredients of job adequacy. Specifically, the social relations of education - the relationships between administrators and teachers, teachers and students, students and students, and students and their work - replicate the hierarchical division of labor. Hierarchical relations are reflected in the vertical authority lines from administrators to teachers to students. Alienated labor 
is reflected in the student's lack of control over his or her education, the alienation of the student from the curriculum content, and the motivation of school work through a system of grades and other external rewards rather than the student's integration with either the process (learning) or the outcome (knowledge) of the educational 'production process'. Fragmentation in work is reflected in the institutionalized and often destructive competition among students through continual and ostensibly meritocratic ranking and evaluation. By attuning young people to a set of social relationships similar to those of the work place, schooling attempts to gear the development of personal needs to its requirements.

Largely because of $S C A$ 's endorsement by the Open University - a very influential body at the time ( $S C A$ was an Open University set book), $S C A$ had a very wide influence, including becoming a central feature of sociology A-level in schools. $S C A$ has been a major progressive force, and the critique of $S C A$, which follows, therefore, should be read not as an attempt to undermine the positive political impact of the book. Instead, it should be viewed as comradely criticism, designed to move forward Marxist theory, and Marxist analysis of schooling and education.

In the Classical Age of Marxist Educational Theory (Rikowksi, 2004), from the early 1970s to the early 1980s, most of the critiques of Bowles and Gintis were from within the Marxist tradition. One of the most influential was Paul Willis's (1977) Learning to Labour. Willis, in fact, turns the correspondence principle on its head. Schooling, for Willis, delivered 'the lads' as compliant factory workers by failing to manipulate the personalities of pupils to produce ideal workers. Anxious to leave school at the earliest opportunity, 'the lads' actually prepared themselves, through their cultural rebellions (having a 'laff' at the school's expense), through their sexism and racism, for the macho and racist world of shop floor life.

\section{Education and the undermining of capitalism ${ }^{3}$}

Madan Sarup (1978, pp. 172-184; see also Apple, 1979, 1982; Giroux, 1981, 1983) makes a number of neo-Marxist criticisms of $S C A$. In particular, he criticises $S C A$ for its functionalism and determinism. Although Bowles and Gintis have a Marxist commitment to overthrowing capitalism, Sarup suggests that their view of society is functionalist and economic determinist. In other words, the impression one gets from reading $S C A$ is that everything is 'sewn up' and totally resistant to change - schooling produces the workforce that capitalism requires and there is not much that can be done about it.

While this determinist reading of $S C A$ must always be considered alongside the two final chapters of the book where Bowles and Gintis address 'Educational Alternatives' (which they debunk) and 'Education, Socialism and Revolution' (where they end the book with a plea for the revolutionary transformation of the US economy), these problems of functionalism and determinism remain. Understandably, commentators concentrated on the central theme of SCA, The Correspondence Principle. Glenn Rikowski (1997a, pp. 551-574) has outlined five interlinked 'debilitating problematics' with Bowles and Gintis's thesis, and the Marxist educational theory that it spawned.

The first is the base/superstructure model, where the economic base determines the superstructure (e.g. the political, legal and, in this case, the schooling system). As Rikowski (1997, p. 556) points out, such determinism leaves no theoretical space for class struggle and engenders fatalism. As noted above, while this critique is valid, it needs to be considered in the light of the last two 
chapters of $S C A$.

Rikowski's second problematic, which leads on from this, is that the correspondence principle's essential functionalism militates against Marxism. While Marxism is, like functionalism, also centrally concerned with how societies function, Marxism is not just a theory of society, but also a theory against society; a theory which moves beyond presently existing society, in the pursuit of a socialist future (ibid., p. 557). This is also a valid point, but also needs considering alongside the last two chapters of $S C A$.

Rikowski's third point is that, in order to escape the base/superstructure dilemma, a number of commentators (e.g. Apple, 1982; Carnoy and Levin, 1985) have drawn on relative autonomy theory, derived from the work of Althusser and others, where there is a degree of autonomy or separateness between the requirements of the capitalist economy (the base) and what happens at the superstructural level of society (education, the political system, etc.). Relative autonomy theorists talk about determination 'in the last instance'. This was seen to offer the best of both worlds: a weak form of determination; and a space for resistance (Rikowski, 1997, p. 558). Problems with relative autonomy theory are determining when 'the last instance' actually arrives; and the tendency for relative autonomy to slide into complete autonomy, thus deserting the Marxist project altogether.

Fourth, the seeming lack of space for resistance in $S C A$ led a number of commentators (e.g. Willis, 1977; Apple, 1982) to concentrate on the ways in which pupils/students resist capitalist schooling. The problem with these writings on resistance, however, is the unspecificity of the term, which, Rikowski (1997, p. 561) argues, thus renders it redundant. Resistance, in the work of the resistance theorists, has included, for example, fucking, fighting, farting, fiddling, anti-intellectualism, racism and sexism (Rikowski, 1997, p. 561).

Rikowski's (1997) fifth and final point is the dichotomy between education for autonomy and social revolution, his argument being that there is a danger that, at the expense of enhancing the individual's capacity for independent thinking, we may lose sight of Marxism's stress on social revolution. While this dichotomy may be true of other (Marxist) writings in the 1970s and 1980s, in the final two chapters of $S C A$, as emphasized above. Bowles and Gintis make it perfectly clear that their overriding concern is with social revolution. As they end their book:

the political challenge facing us [cannot] be met through the spontaneous efforts of individuals or groups working in isolation. The development and articulation of the vision of a socialist alternative, as much as the ability to meet today's concrete human needs requires a mass based party able to aid in the daily struggles of working people throughout the United States and committed to a revolutionary transformation of the U.S. economy(Bowles and Gintis, 1976, p. 288)

Rikowski's solution to the dilemmas of the correspondence principle and its legacy is to dissolve Marxist sociology of education altogether and to make the concept of labour power the starting point for an analysis of the relationship between schooling and capitalism. It is well known that the starting point of Marx's major work, Capital, is an analysis of commodities, the accumulation of which underpins the capitalist mode of production (Marx, 1887 [1965], p. 35). 
Citing Marx (1863) [1969], p. 167), Rikowski (2000, p. 20) makes it clear that there are two classes of commodities: first, labour power; second, commodities distinct from labour power. Labour power is the individual's power to work in order to produce surplus value and is an internal commodity. Those commodities which are external to people include physical objects (such as the products of workers' labour), but also services and intellectual property (e.g. knowledge). Labour power is unique in that it is the only commodity, which produces a value greater than itself (when workers engage in capitalist production, they get paid less than the value they produce, the surplus being appropriated, or hived off, by the capitalist). What characterises the capitalist mode of production is that education and training socially produces labour power. In capitalist society, labour power takes the form of human capital - the capacity of workers to work and, therefore, to produce surplus value.

With increasing globalisation, in order to compete with other capitalists, capitalists need labour power with more human capital than their competitors. The 'intentionality and social drive to reduce education and training to the social production of labour power in capitalism', as Rikowski (2000, p. 23) argues, therefore grows 'stronger with time'. This growth in strength is apparent in the global drive to privatise schooling, both in order to increase profits from the schooling process itself, and in the attempt to massively increase capitalist control over the form and content of schooling.

Despite this intense drive by capital, because of a fatal flaw in this development, Rikowski (2004) is optimistic about the possibility of education as a force for opposing this process. As he argues:

The significance of a politics of human resistance is that labour-power, as a phenomenon is capital's weakest link, in a double sense. First, the transformation of labour-power into labour in the labour process by labourers creates value and surplus-value, the latter being the first form of capital. The whole system depends on labour-power. Secondly, labour-power is an aspect of personhood, and hence under the sway of a will potentially hostile to the social domination of capital in education, and indeed the whole of social life. Thus, an anti-capitalist education of the future might embrace a politics of human resistance to the capitalisation of humanity through education and training being implicated in the social production of labour-power. Education and training would be at the forefront in the politics of human resistance.

Many Marxists would continue to argue, with Marx and Engels, that it is the working class who remain likely to be at the forefront. However, many would also agree that education can play an important role in such resistance.

$S C A$ and the correspondence principle were indeed revolutionary moments in the sociology of education. While a focus on the capitalist economy, provided by the correspondence principle, is welcome to Marxists (and while they laud Bowles and Gintis's (1976) uncompromising commitment to social revolution); another view (Rikowski's), as noted above, is the dissolution of Marxist sociology of education altogether and the building and development of an understanding of the schooling/capitalist economy relation around the material concept of labour power - to return to Marx in order to develop a Marxist educational theory for the twenty-first century. 


\section{Marxism, Education and the undermining of capitalism today}

One British example of an alternative model and approach to higher education (HE) which centralizes Marx and Marxist theory in an educational setting and places the role of educational workers and students as key in the resistance to capitalism is the 'Student as Producer' model of HE which was adopted by the University of Lincoln in 2010. This model, which cements theory and practice (praxis), is in stark contrast to and is actively and openly subversive of the neoliberal model and the direction of Higher Education in England (see Maisuria and Cole, 2017, for a discussion of this neoliberalization of HE). The 'Student as Producer' model was written up as a core component of the University's Teaching and Learning Plan 2011-2016. As one of the founders of the project, Professor Mike Neary, writing with Lecturer and $\mathrm{PhD}$ student in alternative education Gary Saunders put it:

'Student as Producer' is an act of resistance to the current policy framework being imposed on universities in England and around the world; and, as such, is a critical response to attempts by national governments to create and consolidate a consumerist culture and impose high levels of debt among undergraduate students' (Neary and Saunders, 2016, p. 2).

'Student as Producer', they go on, 'emerged from this double crisis: a socio-economic crisis and an associated crisis over the meaning and purpose of higher education', and 'identifies strongly with the academic and student movement of protests against fees and cuts to funding in higher education and other social and welfare services' (p. 2).

Countering the increasingly dominant hegemony of the neoliberal modelling of the university, 'Student as Producer', taking its title from Walter Benjamin's The Author as Producer, in which Benjamin argues that not only should intellectual authors produce revolutionary publications, they should also seek to transform the social relations of production for a communist society, 'is framed around the practices and principles of critical pedagogy ${ }^{4}$, popular education and Marxist theory'With respect to Marxist theory, in addition to the inspiration deriving from Benjamin, Neary and Saunders (2016, p. 2) refer to Thomas Mathiesen's notion of the 'politics of abolition' and his underpinning concept of 'the unfinished' (Mathiesen, 1974, cited in Neary and Saunders, 2016, p. 3). This negative attitude understands capitalist repression as related to the domination of the labour theory of value (it is the labour of the worker that creates value, and surplus value is appropriated from workers by capitalists in the act of production: hence capitalism is inherently exploitative), and its institutional forms of regulation: money and the state (Clarke, 1991; Postone, 1993, cited in Neary and Saunders, 2016, p. 3). In this way, 'revolutionary knowledge is understood as something that is constituted through class-struggle, co-operation and radical practice, where the crisis of the capitalist university becomes a field of radical research to be reconstituted as a form of subversive 'living knowledge' (Roggero, 2011, p. 8, cited in Neary and Saunders, 2016, p. 3).

"Student as Producer" is based on Marx's early writings promoting conditions where students can recognise themselves in a world of their own design (Neary and Saunders, 2016, p. 11). However, as Neary and Saunders (2016, pp. 3-4) stress, despite the recognition of 'Student as Producer' by the University of Lincoln, that university remains a neoliberal institution, 'existing within an increasingly marketised system, committed to the way academic values are being defined with the current higher education context.' This is in the context of the intensification of neoliberalism, 
which, as we shall shortly see, led to a group of academics at Lincoln taking the radical principles that underpin 'Student as Producer' outside the university to establish an autonomous critical pedagogical project, the Social Science Centre (SSC).

'Student as Producer' is existing both in and against the university, and also in and against the neoliberal state, and refuses to privilege the working class (defined as blue collar workers, peasants and factory workers) as the only revolutionary agents of change within capitalist social relations (Neary and Saunders, 2016, p. 7; see also Postone, 1993; Holloway, 2002; Larsen et al, 2014). As Neary and Saunders (2016, p. 8) put it, 'forms of revolutionary subjectivity are derived from antagonisms to capitalist work and non-work inside and outside of the capitalist factory and other forms of repressive institutional life, including the university' . Therefore revolutionaries consist not only of industrial workers at work, but also domestic workers, the unemployed, migrants and others who are struggling against the politics of poverty and scarcity that characterise capitalist life; and also students and academics inside the edu-factory (Edu-factory Collective, 2009, cited in Neary and Saunders, 2016, p. 8). The parameters of the potentially revolutionary working class include a wider range of workers and those who are alienated and exploited by the ruling class. The working class is therefore that large proportion of people who need to work and produce value in the neoliberal mode of production. If they did not work they would struggle to survive, live, and flourish. Therefore, even highly paid workers, perhaps in professional positions such as academics, are still workers, albeit with a greater share of expendable income than traditional blue collar and service sector workers. This definition of the working class also includes those who are out of, or in flexible, employment - they need to work, and when they do not, they serve the function of a reserve army of labour. The reserve army of labour are those people who are surviving precariously, and used by the neoliberal capitalist system, implicitly and explicitly, to threaten all those in those work to comply or be replaced.

'Student as Producer' can be seen as 'an act of collaboration between students and academics in the making of practical-critical knowledge' - it could be described as a form of ongoing participatory action research with a militant tendency (Neary and Saunders, 2016, p. 9) which started in 2007 when marginalised and disenfranchised academic workers, students and staff were contacted to celebrate radical pedagogical practices (p. 9). However by 2011, Neary and Saunders (2016, p. 14) felt that the processes set to maintain the dissensual incorporation of 'Student as Producer' 'appeared to have turned into just another bureaucratic management procedure', and, faced with what appeared to be defeat, in that year a group of Lincoln University staff set up the Social Science Centre, Lincoln (p. 15), which has no formal relationship with the university.

In its own words, and drawing on basic socialist principles:

The Social Science Centre offers opportunities to engage in a co-operative experience of higher education. Run as a not-for-profit co-operative, the SSC is organised on the basis of democratic, non-hierarchical principles, with all members having equal involvement in the life and work of the SSC. [Staff and students at the centre] study themes that draw on the core subjects in social science: sociology, politics and philosophy, as well as psychology, economics, journalism and photography. The Centre organises study and research at all levels including undergraduate, Masters and Doctorates in Philosophy.The co-operative principles that guide the organisation of the SSC also extend to the ways in which we design and run our courses. All classes are participative and collaborative in 
order to ground inquiry in the experiences and knowledges of the participants. Studentscholars and teacher-scholars have opportunities to design courses together, and those new to teaching and independent learning are offered generous support from others. All members are able to work with academics and other experienced researchers on research projects, and to publish their own writings through the SSC. One key guiding principle of the Centre is that 'teachers' and 'students' have much to learn from each other (The Social Science Centre, Lincoln, 2016).

\section{Contemporary Challenges to Marxism}

Marxism has been subject to sustained critique not just from the Right and Centre but from those on the 'left of centre' politically ever since the sociologist Max Weber extensively challenged Marxist ideas and concepts. Such 'Left' critiques have included poststructurlism and postmodernism (see Cole, 2008, chapter 5 for a Marxist critique) and more recently Critical Race Theory and Intersectionality.

\section{Critical Race Theory and the Primacy of 'Race' Over Class}

One of the central tenets of Critical Race Theory (CRT) is that the main form of oppression is society is based on 'race' rather than class (see Cole, 2017a, b for Marxist critiques). While there is some evidence of a recent move towards intersectionality (Cole, 2017b), a belief in the primacy of 'race' over class remains axiomatic to CRT. That this is the case within CRT has been clearly explained by Critical Race Theorist Charles W. Mills. Mills rejects both what he refers to as the 'original white radical orthodoxy (Marxist)' for arguing that social class is the primary contradiction in capitalist society, and the 'present white radical orthodoxy (postMarxist/postmodernist)' for its rejection of any primary contradiction. Instead, for Mills, 'there is a primary contradiction, and ... it's race' (Mills, 2003, p. 156). For founding Critical Race Theorist Kimberlé Crenshaw and colleagues, 'subsuming race under class' is 'the typical Marxist error' (Crenshaw et al, p. xxvi).

Mills states that '[r]ace [is] the central identity around which people close ranks' and that there is 'no transracial class bloc' (Mills, 2003, p. 157). Given the way in which neoliberal global capitalism unites capitalists throughout the world on lines that are not necessarily colour-coded, this statement seems quite extraordinary.

'Race', Mills goes on, is 'the stable reference point for identifying the "them" and "us" which override all other 'thems' and "us's" (identities are multiple, but some are more central than others)' (Mills, 2003, p. 157), while for Crenshaw and colleagues, although they acknowledge that 'race' is socially constructed (with which (modern-day) Marxists would fully concur), 'race' is also 'real' since 'there is a material dimension and weight to being "raced" in American society' (Crenshaw et al, 1995, p. xxvi). It is true that racism, of course, has real material effects on racialized peoples, not just in the US, but throughout the world. 'Race', Mills concludes, is 'what ties the system together, and blocks progressive change' (Mills, 2003, p. 157). For Marxists, it is capitalism that does this.

Mills invites readers to:

Imagine you're a white male Marxist in the happy prefeminist, pre-postmodernist world of a quarter-century ago. You read Marcuse, Miliband, Poulantzas, Althusser. You believe in a theory of group domination involving something like the following: The United States is a class society in which class, defined by relationship to the means of production, is the 
fundamental division, the bourgeoisie being the ruling class, the workers being exploited and alienated, with the state and the juridicial system not being neutral but part of a superstructure to maintain the existing order, while the dominant ideology naturalizes, and renders invisible and unobjectionable, class domination (Mills, 2003, p. 158).

Bearing in mind the aforementioned important caveat that twenty-first century Marxists are inclusive with respect to identities in addition to social class, this all seems a pretty accurate description of the United States in the twenty-first century, but for Mills it is 'a set of highly controversial propositions' (Mills, 2003, p. 158). He justifies this assertion by stating that all of the above 'would be disputed by mainstream political philosophy (liberalism), political science (pluralism), economics (neoclassical marginal utility theory), and sociology (Parsonian structural-functionalism and its heirs)' (Mills, 2003, p. 158). While this is true, the reason it would be disputed by mainstream philosophers, pluralist political scientists, neoclassical economists and functionalist sociologists is because all of them, unlike Marxists, are, at one level or another, apologists for capitalism.

Social class, Marxists would argue, albeit massively racialized and gendered, is the system upon which the maintenance of capitalism depends. It is possible, though extremely difficult, because of the multiple benefits accruing to capital of racializing workers (not least forcing down labour costs), and the unpaid and underpaid labour of women as a whole, to imagine a capitalist world of 'racial' and gender equality. It is not logically possible for capitalism to exhibit social class equality. Without the extraction of surplus value from the labor of workers, capitalism cannot exist.

\section{Intersectionality CRT and Marxism}

If CRT is a major 'Left' paradigm for understanding racism, one of the foremost manifestations of contemporary feminism that links gender with 'race' and other forms of oppression is intersectionality. As Marxist feminist Eve Mitchell puts it, '[t]oday, you could go into any university, on any number of liberal-to-left blogs or news websites, and the words "identity" and "intersectionality" will jump out [at] you as the hegemonic theory' (Mitchell, 2013, p. 1). What then is 'intersectionality'? I will begin my explanation by comparing it to CRT. This comparison is articulated by leading British Critical Race Theorist, David Gillborn.. As he points out, critical race theorists 'often focus on how racism works with, against and through additional axes of differentiation including class, gender, sexuality and disability' (Gillborn, 2008, p. 37). Hence, there are a number of identity-specific varieties such as 'LatCrit', 'Asian-American jurisprudence', 'Native jurisprudence', and 'queer-crit', (Cole, 2016a) as well as critical race theorists who focus on oppression based on disability. As Gillborn argues, this concern with intersectionality is especially strong in critical race feminism (Gillborn, 2008, p. 36), itself a variety of CRT. Indeed, the very concept of intersectionality is generally attributed to the aforementioned feminist critical race theorist Kimberlé Crenshaw in an article in 1989, in which she sought to challenge both feminist and antiracist theory and practice that neglected to 'accurately reflect the interaction of race and gender' (Crenshaw, 1989, p. 140). As she reasoned, 'because the intersectional experience is greater than the sum of racism and sexism, any analysis that does not take intersectionality into account cannot sufficiently address the particular manner in which Black women are subordinated' (ibid., p. 140). A key aspect of intersectionality is its 
premise that multiple oppressions are not each suffered separately, but as a single, synthesized experience (Smith, 2013/14, p. 3).

Prominent UK-based intersectionality theorist Nira Yuval-Davis states that unlike 'many feminists, especially black feminists, who focus on intersectional analysis as specific to black and ethnic minorities women or, at least, to marginalized people', she sees 'intersectionality as the most valid approach to analyze social stratification as a whole'. Intersectional analysis, she claims, 'does not prioritize one facet or category of social difference'. 'As to the question of how many facets of social difference and axes of power need to be analyzed', she clarifies her view of its fluidity:

this is different in different historical locations and moments, and the decision on which ones to focus involve both empirical reality as well as political and especially ontological struggles. What is clear, however, is that when we carry out intersectional analysis, we cannot homogenize the ways any political project or claimings affect people who are differentially located within the same boundaries of belonging (Yuval-Davis, 2011, p. 4).

Intersectionality can be merely an academic discipline, divorced from class struggle, or it can be a healthy counterbalance to what remains of reductionist Marxism, which views any consideration of oppression and exploitation beyond social class to be diversionary. At its worst, intersectionality simply creates 'a list of naturalized identities, abstracted from their material and historical context' (Mitchell, 2013, p. 7), of which the 'practical upshot ... is the perpetual articulation of difference, resulting in fragmentation and the stagnation of political activity' (Rectenwald, 2013, p. 2). Intersectionality viewed thus, renders social class as non-axiomatic, not the crucial social relation on which depends the ability or otherwise of capitalism to sustain and reproduce itself.

At its best intersectionality is 'rooted in real material conditions structured by social class' (Patricia Hill Collins, cited in Guy-Sheftall, 1995, p. 345). As Sharon Smith concludes, as 'an additive to Marxist theory, intersectionality leads the way toward a much higher level of understanding of the character of oppression than that developed by classical Marxists' (Smith, 2013/14, p. 13, emphasis added). Underlying the Marxist position that no academic political theory is valid if it is disconnected from workers' struggles and the need for praxis, Smith adds that intersectionality thus defined enables 'the further development of the ways in which solidarity can be built between all those who suffer oppression and exploitation under capitalism to forge a unified movement' (Smith, 2013/14, p. 13).

\section{Conclusion}

In this entry, I began by considering Marx and Engels on education. I went on to look at education and the reproduction, focusing on some of the work of Althusser and Bowles and Gintis. I then turned my attention to education's role in undermining capitalism. Here I devoted my attention to Rikowski's critique of Bowles and Gintis. Next, I discussed a British example of an alternative socialist model of education, the 'Student as Producer'. I concluded with a discussion of contemporary challenges to Marxism, focusing on CRT and Intersectionality. Such challenges will no doubt continue in various forms. It is my contention, however, that the case for relevance of Marx and a socialism of the twenty-first century remains imperative - indeed 
ever more so in the era of austerity (Cole, 2017b), of Trump (Cole, 2018) and of increased political polarisation.

\section{Notes}

${ }^{1}$ Cole (2018) also addresses Donald J. Trump, the alt-right and public pedagogies of hate and for fascism (chapters 1 to 4) and the reality of Trump's America and general resistance to Trump, and to fascism, focusing on Antifa (chapter 5).

${ }^{2}$ The extent to which Althusser might have modified his views on education being the dominant $I S A$, given the current hegemony of other ISAs such as the 'political' and the 'cultural' (e.g. mass media) is open to debate.

${ }^{3}$ The following analysis is based on Cole, 2008, pp. 33-36

${ }^{4}$ Neary and Saunders do not offer explanations of what they mean by 'critical pedagogy'. Ira Shor defines the concept as:

Habits of thought, reading, writing, and speaking which go beneath surface meaning, first impressions, dominant myths, official pronouncements, traditional cliches, received wisdom, and mere opinions, to understand the deep meaning, root causes, social context, ideology, and personal consequences of any action, event, object, process, organization, experience, text, subject matter, policy, mass media, or discourse $(1992,129)$.

Critical pedagogy's origins can be traced back to the classic (1968) text of Brazilian education Paulo Freire, entitled Pedagogy of the Oppressed. In this book, Freire used the term, conscientization (becoming critically conscious), or conscientização in Portuguese, to describe how the teacher should work to lead students to question these habits and to encourage libratory collective and idividual responses to their oppression in order to strive to overcome it. Along with Ira Shor, one of the most prolific and well-known advocates of critical pedagogy is Peter McLaren, e.g. Che Guevara, Paulo Freire, and the Pedagogy of Revolution (McLaren, 2000, 160-169) and Life in Schools: An Introduction to Critical Pedagogy in the Foundations of Education (2016, Part 3). In the first edition of McLaren's Life in Schools in 1989, Freire wrote, 'McLaren's work is a passionate challenge to all forms of education that limit rather than enhance the project of human emancipation ... It is a book that should be read by all'. McLaren (2000, pp. 193-194) is disapproving of reformist critical pedagogy scholars who wish to limit Freire's work to its contribution to consciousness-raising, while leaving intact the existing structures of society. In his later writings, partly as a result of this, McLaren has advocated revolutionary critical pedagogy combined with liberation theology. As he puts it, in a definition that includes a space for public pedagogy:

The concept of a revolutionary critical pedagogy implies some form of relation between knowledge of a domain formally constituted as 'the social setting' in which learning takes place (such as classrooms) and another domain formally constituted as 'the pedagogical' or where 'teaching' occurs in the most general sense (and this includes venues other than classrooms) (McLaren, 2015, 35).

Revolutionary critical pedagogy is essentially Marxist (aiming to replace capitalist society with true democratic socialism). For McLaren, revolutionary critical pedagogy also values contributions from liberation theologians (those, like Freire, who combine Marx with Jesus) (McLaren, 2015, 35; for an elaboration of combining revolutionary critical pedagogy with liberation theology, see McLaren and Jandrić, 2017). For a critical appraisal of McLaren 2015, see Neary, 2017.

\section{References}


Althusser, L. (1971) 'Ideology and Ideological State Apparatuses', in Lenin and Philosophy and Other Essays, London: New Left Books. www.marx2mao.com/Other/LPOE70ii.html\#s5

Apple, M. W. (1979) Ideology and Curriculum, London: Routledge

Apple, M. W. (1982) Education and Power, Boston: Ark Paperbacks.

Benjamin, W. (1934) [1970] 'The Author as Producer' New Left Review I/62, July-August http://www.celinecondorelli.eu/files/benjamin-the-author-as-producer.pdf

Bowles, S. and Gintis, H. (1976) Schooling in Capitalist America: Educational Reform and the Contradictions of Economic Life, New York: Basic Books

Carnoy, M. and Levin, H. (1985) Schooling and Work in the Democratic State, Stanford: Stanford University Press.

Clarke, S. (1991). Marx, marginalism and modern sociology. 2nd Edition. Basingstoke: MacMillan.

Cole, M. (2008) Marxism and Educational Theory: Origins and Issues, London: Routledge

Cole, M. (2017a) Critical Race Theory and Education: A Marxist Response, $\mathbf{2}^{\text {nd }}$ Edition, New York and London: Palgrave Macmillan

Cole, M. (2017b) New Developments in Critical Race Theory and Education: Revisiting Racialized Capitalism and Socialism in Austerity, New York and London: Palgrave Macmillan

Cole, M. (2018) Trump, the Alt-Right and Public Pedagogies of Hate and For Fascism: What is To Be Done?, London and New York: Routledge

Crenshaw, K. (1989) 'Demarginalizing the intersection of race and sex: a black feminist critique of antidiscrimination doctrine, feminist theory, and antiracist politics', University of Chicago Legal Forum

Crenshaw, K. Gotanda, N., Peller, G., and Thomas, K. (1995) 'Introduction', in Crenshaw, K. Gotanda, N., Peller, G., and Thomas, K. (eds) Critical Race Theory: The Key Writings that Formed the Movement, New York: New Press.

Edu-factory Collective (2009). Towards a global autonomous university. New York: Autonomedia.

Engels, F. (1845) [1975] 'Speeches in Elberfeld', Marx and Engels, Collected Works, Volume 4.

Engels, F. (1892) [1977] 'Socialism: Utopian and Scientific', in Karl Marx and Frederick Engels: Selected Works in One Volume, London: Lawrence and Wishart. 
Freire, P. (1968) Pedagogy of the oppressed, New York: Seabury Press.

Gillborn, D. (2008) Racism and Education: Coincidence or Conspiracy? London: Routledge.

Giroux, H. (1981) Ideology, Culture and the Process of Schooling, Philadelphia: Temple University Press.

Giroux, H. (1983) Theory and Resistance in Education: A Pedagogy for the Opposition, South Hadley: Bergin and Garvey.

Guy-Sheftall, B. (1995) Words of Fire: An Anthology of African-American Feminist Thought, New York: New Press.

Holloway, J. (2002). Change the world without taking power: the meaning of revolution today. London and New York: Pluto Press.

Johnson, R. (1979) “"Really useful knowledge': radical education and working-class culture, 1790-1848”, in J. Clarke, C. Critcher and R. Johnson (eds) Working Class Culture: Studies in history and theory, London: Hutchinson in association with the Centre for Contemporary Cultural Studies, University of Birmingham

Larsen, N., Nilges, M., Robinson J, \& Nicholas, B. (2014). Marxism and the critique of value. Chicago: MCM'Publishing.

Marx, K. (1863) [1969] Theories of Surplus Value - Part One, London: Lawrence and Wishart

Marx, K. (1887) [1965] Capital Vol. 1, Moscow: Progress Publishers.

Maisuria, A. and Cole, M. (2017) 'The neoliberalization of higher education in England: An alternative is possible', Policy Futures in Education, 15 (5)

Mathiesen, T. (1974). The politics of abolition: Scandanavian studies in criminology. Oslo: Martin Robertson.

McLaren, P. 2000. Che Guevara, Paulo Freire, and the Pedagogy of Revolution. Lanham, Maryland: Rowman and Littlefield.

McLaren, P. (2015) Pedagogy of Insurrection: From Resurrection to Revolution, New York: Peter Lang.

McLaren, P. 2016. Life in Schools: An Introduction to Critical Pedagogy in the Foundations of Education. New York: Routledge. 
McLaren, Peter and Jandrić, P. (2017) 'From liberation to salvation: Revolutionary critical pedagogy meets liberation theology', Policy Futures in Education, 15 (5).

\#Mills, C. W. 2003) From Class to Race: Essays in White Marxism and Black Radicalism, Lanham, Md.: Rowman and Littlefield.

Mitchell, E. (2013) 'I am a woman and a human: a Marxist feminist critique of intersectionality theory' libcom.org https://libcom.org/library/i-am-woman-human-marxist-feminist-critiqueintersectionality-theory-eve-mitchell

Neary, M. (2017) 'Pedagogy of Hate', Policy Futures in Education, 15 (5)

Neary, M. and Saunders, G. (2016) 'Student as Producer and the Politics of Abolition Making a New Form of Dissident Institution?' Critical Education 7 (5), March 15

Postone, M. (1993). Time, labour and social domination: A reappraisal of Marx's theory.

Cambridge: Cambridge University Press.

Price, R. F. (1977) Marx and Education in Russia and China, London: Croom Helm

Quijano, A. and Ennis, M. (2000) 'Coloniality of Power, Eurocentrism, and Latin America', Nepantla: Views from South 1 (3).

Rectenwald, M. (2013) 'What's Wrong With Identity Politics (and Intersectionality Theory)? A Response to Mark Fisher's "Exiting the Vampire Castle" (And Its Critics), North Star, December 2 http://www.thenorthstar.info/?p=11411

Rikowski, G. (1997) 'Scorched Earth: Prelude to Building Marxist Educational Theory, British Journal of Sociology of Education 18 (7) http://www.tandfonline.com/doi/abs/10.1080/0142569970180405? journalCode=cbse20

Rikowski, G. (2000) 'That Other Great Class of Commodities: Repositioning Marxist Educational Theory', paper presented at the British Educational Research Association Conference, Cardiff University, 7-10 September 2000 Education-Line http://www.leeds.ac.uk/educol/documents/00001624.htm

Rikowski, G. (2004) 'Marx and the Education of the Future', Policy Futures in Education, 2 (3 and 4) http://pfe.sagepub.com/content/2/3-4/565.full.pdf + html

Roggero, G. (2011). The production of living knowledge: The crisis of the university and the transformation of labour in Europe and North America. Philadelphia, PA: Temple University Press.

Sarup, M. (1978) Marxism and Education, London: Routledge and Kegan Paul.

Shor, I. (1992) Empowering Education: Critical Teaching for Social Change. Chicago: University of Chicago Press, 
Smith, S. (2013/14) 'Black feminism and intersectionality' International Socialist Review, 91

Taylor, G. 'Socialism and Education: 9. Marx on Education, Industry and the Fall of Capitalism', General Educator: Journal of Natfhe General Education Section, Issue 35, July-August.

The Social Science Centre, Lincoln (2016) 'The Social Science Centre, Lincoln: About Us' http://socialsciencecentre.org.uk/about/

Willis, P. (1977) Learning to Labour: How Working Class Kids Get Working Class Jobs, Farnborough: Saxon House.

Yuval-Davis, N. (2011) 'Power, intersectionality and the politics of belonging' Aalborg: Institut for Kultur og Globale Studier, Aalborg Universitet, Denmark

http://vbn.aau.dk/files/58024503/FREIA_wp 75.pdf 